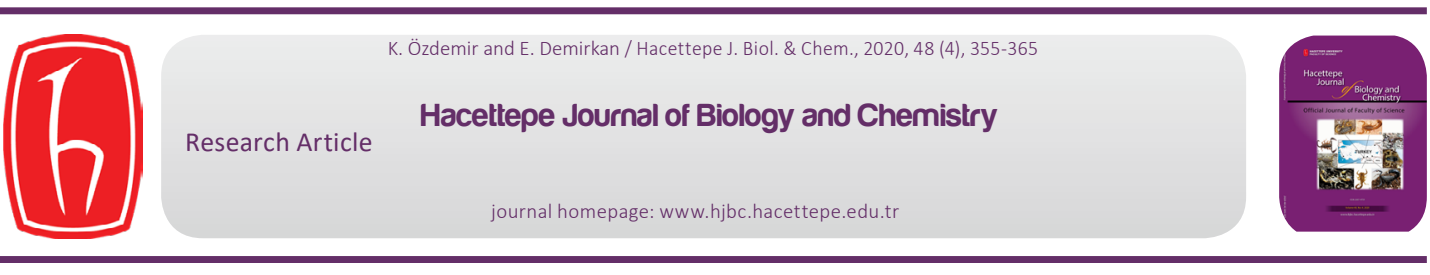

\title{
Ethyl Methanesulfonate (EMS) Mutation for Hyper Protease Production by Bacillus subtilis E6-5 and Optimization of Culture Conditions
}

\section{Bacillus subtilis E6-5'dan Yüksek Proteaz Üretimi için Etil Metansülfonat (EMS) Mutasyonu ve Kültür Koşullarının}

\section{Kübra Özdemir ${ }^{*}$ and Elif Demirkan}

Bursa Uludag University, Faculty of Arts and Sciences, Biology Department, Bursa, Turkey.

\section{ABSTRACT}

\begin{abstract}
$\mathrm{n}$ this study is aimed the improvement of Bacillus subtilis E6-5 for high protease production by EMS treatment as chemical mutagen. The 82 mutants were screened on skim milk agar plates and, the mutant with maximum protease activity was named KE20. The mutant was quantitatively tested, and showed 9.2 times more protease activity than the parental strain. The effects of nutritional and physical factors on the protease production of mutant KE2O were investigated. The best carbon and nitrogen sources were corn starch and skim milk. No effect was observed when metal ions were used alone. In the physical parameters, the best results were obtained at $37^{\circ} \mathrm{C}, \mathrm{pH} 7.0,150 \mathrm{rpm}, 3 \%$ as inoculum size and 18 has inoculum age. A new medium was made by optimizing the incubation conditions and enzyme yield enhanced $79 \%$ compared to basal medium. The mutant KE20 strain may have a prominent potential for protease production on an industrial scale.
\end{abstract}

Key Words

Bacillus, protease, EMS mutagenesis, optimization.

öz

\begin{abstract}
u çalışmada, kimyasal mutajen olarak EMS tedavisi ile yüksek proteaz üretimi için Bacillus subtilis E6-5'in geliştirilmes amaçlanmıştır.82 mutant yağsız süt agar plakaları üzerinde tarandı ve maksimum proteaz aktivitesine sahip mutant KE20 olarak adlandırıldı. Mutant kantitatif olarak test edildi ve ana suşdan 9.2 kat daha fazla proteaz aktivitesi gösterdi. KE20 mutantının proteaz üretimine beslenme ve fiziksel faktörlerin etkileri araştırıldı. En iyi karbon ve azot kaynakları mısır nişastası ve yağsız süt idi. Tek başına metal iyonları kullanıldığında hiçbir etki gözlenmemiştir. Fiziksel parametrelerde en iyi sonuçlar $37^{\circ} \mathrm{C}, \mathrm{pH}$ 7.0, $150 \mathrm{rpm}$, inokülasyon hacmi olarak \%3 ve inokülasyon yaşı olarak 18 saatte elde edildi. İnkübasyon koşulları optimize edilerek yeni bir ortam hazırlandı ve bazal ortama kıyasla enzim verimi \% 79 arttı. Mutant KE20 suşu, endüstriyel ölçekte proteaz üretimi için önemli bir potansiyele sahip olabilir.
\end{abstract}

Anahtar Kelimeler

Bacillus, proteaz, EMS mutajenezi, optimizasyon.

Article History: Received: Mar 02, 2020; Revised: May 21, 2020; Accepted: Aug 21, 2020; Available Online: Sep 28, 2020 DOI: https://doi.org/10.15671/hjbc.697070

Correspondence to: E. Demirkan, Bursa Uludag University, Faculty of Arts and Sciences, Biology Department, Bursa,Turkey. E-Mail: kubraozdemir016@gmail.com 


\section{INTRODUCTION}

Prot roteases, or proteolytic enzymes is one of the most important industrial enzymes using in biotechnological fields. It shares $60 \%$ of total worldwide sale of industrial enzymes [1] and widely used in several industries that include leather processing, meat processing, dairy, preparation of organic fertilizer, silk industry, laundry detergents, pharmaceutical industries, cosmetics, contact lens solutions, face masks, skin cleansers, hair care creams, toothpaste and also for the recovery of silver from used X-ray films. Proteases occur in animals, plants and microorganisms [2]. But microorganisms are used in industrial production. Because, microorganisms produce enzymes easily and faster than mammalian and plant cells. It have reported that many microorganisms are capable of producing proteases, such as Aspergillus oryzae [3]. Aureobasidium pullulans [4], Serratia marcescens [5] and Bacillus subtilis [6]. A large proportion of commercial proteases are produced by Bacillus strains [7].

In recent years, the overproduction of enzymes from microorganisms by stimulated mutagenesis has gained importance [8]. It has become a routine practice in the field of biotechnology to obtained a mutant through random mutagenesis [9]. These are their simplicity and low cost procedure as compared to DNA recombinant technology [10]. Frequently, physical (UV) and chemical mutagens (nitrous acid $\left(\mathrm{HNO}_{2}\right), \mathrm{N}$-methyl-N-nitro-N-nitrosoguanidine (MNNG), Ethidium bromide (EtBr), ethyl methyl sulphonate (EMS) are used for random mutagenesis.

Ethyl methanesulfonate (EMS) is a mutagenic alkylating agent. It produces random mutations in DNA by nucleotide substitution, especially by guanine alkylation. EMS typically induces point mutations, and also frame shifts and even chromosome aberrations.

This mutagenic agent has been used for overproduction from microorganmisms of some important industrial enzymes such as amylase, protease, lipase, phytase, cellulase, glucose oxidase, laccase, pectinase and catalase [11]. Some studies have reported that the hyper-proteolytic mutant strains using EMS obtained [12-14].

On the other hand, enzyme production is largely dependent on the condition of growth of the culture and composition of nutrient medium. Therefore, optimization of production medium is required to maximize the metabolite yield.
The present study describes enhanced protease production by the bacterium Bacillus subtilis E6-5 was improved through mutation by radiations (EMS). The hyper- producer strain of protease was selected and the optimization of the nutrional requirements for enzyme production were carried out.

In the present study, parental Bacillus subtilis E6-5 was improved for protease production using ethyl methanesulfonate (EMS) as an inducing chemical mutagen. Cultural conditions such as nutritional and physical factors for enzyme production by hyper protease producer mutant were optimized.

\section{MATERIALS and METHODS}

\section{Microorganism}

The microorganism used in this study was Bacillus subtilis E6-5 which was isolated from soil and identified in our previous study [15].

\section{Ethyl methanesulfonate (EMS)mutagenesis}

Chemical mutagen EMS (Sigma M-0880) used for random mutation was purchased in liquid form. Mutagenesis of Bacillus subtilis E6-5 was carried out using concentrations of $4-400 \mathrm{mg} / \mathrm{ml}$ to determine the EMS concentration causing $99 \%$ lethality rate. The parental strain was grown in nutrient broth medium overnight till density of $10^{8} \mathrm{CFU} / \mathrm{mL}$. Different concentrations of EMS in $5 \mathrm{ml}$ of grown cultures were added under aseptic conditions, and cultures were incubated at $37^{\circ} \mathrm{C}$ and $150 \mathrm{rpm}$ for $10-60 \mathrm{~min}$. Then to remove EMS, cultures were centrifuged at $6000 \mathrm{rpm}$ for $15 \mathrm{~min}$. The pellets were washed twice with sterilized saline water to remove traces of EMS from bacterial cells. The pellet was resuspended in $10 \mathrm{ml}$ of sterilized $0.04 \mathrm{M}$ phosphate buffer ( $\mathrm{pH}$ 7.0). Then, it was serially diluted and, was transferred on the petri plates containing skim milk agar. The plates were incubated for $24 \mathrm{~h}$ at $37^{\circ} \mathrm{C}$, and the appearing number of colonies on each plate was counted. Proteolytic activities of mutants were detected on the basis of appearance of clear zones around the bacterial colonies. The diameters of the clear halo-zone were measured by millimeter ruler. The mutant strain showing the largest protease zone as compared to parental strain was selected, and used in further studies.

The lethality rate was evaluated based on the following equation [16];

Lethality rate $=(\mathrm{U}-\mathrm{T}) / \mathrm{U} \times 100 \%$ 
Where $U$ is the total colony count of the sample without EMS treatment, and T is the total colony count after treatment with EMS.

\section{Protease production}

To evaluate enzyme production, mutant was inoculated in the medium containing ( $\%$ w v-1) glucose-0.1, peptone- 1 , yeast extract-0.02, $\mathrm{MgSO}_{4}-0.01, \mathrm{CaCl}_{2}-0.01, \mathrm{~K}_{2} \mathrm{HPO}_{4}-0.05$ $(\mathrm{pH}$ 7.0) [17]. Glucose was sterilized and added separately to the flasks. The precultures were cultivated in Nutrient Broth medium ( $0.8 \%$ w v- 1 ) for $18 \mathrm{~h}$. Then, overnight cultures with optical density of 0.3 at $600 \mathrm{~nm}$ were inoculated at $1 \%$ in enzyme production media $(150 \mathrm{~mL}$ in $500 \mathrm{~mL}$ erlenmeyer flasks) and incubated at $37^{\circ} \mathrm{C}$ for $18,24,32,44$, $48,52,56$ and 72 hours in a shaking incubator at $150 \mathrm{rpm}$. At the end of each period, the cultures were centrifuged (6000 rpm, $10 \mathrm{~min}$ ) and the supernatants were used for the determination of proteolytic activity. Maximum enzyme production period was determined. Bacterial biomass was determined by measuring optical density at 600 $\mathrm{nm}$.

\section{Enzyme activity}

Total protease activity was measured using casein as substrate by the modification of the Anson Method [18]. $1 \mathrm{~mL}$ of the culture supernatant was mixed with $1 \mathrm{~mL} 0.05 \mathrm{M}$ phosphate buffer-0.1 M NaOH (pH 7.0 adjusted with phosphoric acid) containing $2 \%$ casein, and incubated for 10 $\mathrm{min}$ at $37^{\circ} \mathrm{C}$. The reaction was stopped by adding $2 \mathrm{~mL} 0.4$ $\mathrm{M}$ Trichloroacetic acid. After $20 \mathrm{~min}$ stand at $37^{\circ} \mathrm{C}$, the precipitate was removed by centrifugation at $6000 \mathrm{rpm}$ for 10 min. $1 \mathrm{~mL}$ of the supernatant was treated with $5 \mathrm{~mL} 0.4 \mathrm{M}$ $\mathrm{NaCO}_{3}$ and $1 \mathrm{~mL}$ of diluted Folin-Ciocalteu reagent (1:3). After 20 min of waiting in the dark at room temperature the optical density of the sample was measured at $660 \mathrm{~nm}$. A standard curve was generated using solutions of 0-60 $\mu \mathrm{g} \mathrm{mL^{-1 }}$ tyrosine. One unit of protease activity was defined as the amount of enzyme required to liberate $1 \mu \mathrm{g} \mathrm{mL}^{-1}$ tyrosine under the experimental conditions used.

\section{Effect of Nutrional Factors on Protease Production}

Various carbon sources (0.1\%) such as fructose, glycerol, sucrose, corn starch, wheat starch, potato starch, maltose, wheat bran evaluated for their effect on protease production by replacing glucose in the basal medium.

Organic nitrogen sources chosen for the study were tryptone, meat extract, skim milk, and corn step liquor by replacing peptone and yeast extract (total $1.02 \%)$; and inorganic nitrogen sources were $\mathrm{NH}_{4} \mathrm{NO}_{3^{\prime}} \mathrm{KNO}_{3^{\prime}}\left(\mathrm{NH}_{4}\right)_{2} \mathrm{SO}_{4^{\prime}}$
$\mathrm{NaNO}_{3}$ and $\mathrm{NH}_{4} \mathrm{Cl}_{2}$. These nitrogen sources were used to replace the organic and inorganic source available in the basal medium.

The culture medium was supplemented with the following metal salts (0.02\%) such as $\mathrm{LiSO}_{4}, \mathrm{FeSO}_{4}, \mathrm{KCl}, \mathrm{NaCl}, \mathrm{MnSO}_{4}$ and $\mathrm{ZnSO}_{4}$ replaced with $\mathrm{MgSO}_{4}$ and $\mathrm{CaCl}_{2}$.

Protease activity and biomass were determined for all the samples.

\section{Effect of Physical Factors on Protease Production}

Some parameters (temperature, $\mathrm{pH}$, agitation, inoculum size and inoculum age (days)) were studied for its influence in protease production in basal medium.

The effect of temperature was performed by incubating the reaction mixtures at different temperatures such as 30 , $35,37^{\circ} \mathrm{C}$ (control), 40,45 and $50^{\circ} \mathrm{C}$ in basal medium with optimal $\mathrm{pH}$ of 7.0 .

$\mathrm{pH}$ in the range of 4.0-8.0 were examined for their effect on protease production by the mutant satrain in basal medium.

Effect of agitation condition was carried out at following shaking rate, 0 rpm, 50 rpm, 100 rpm,150 rpm (control) and $200 \mathrm{rpm}$.

The mutant strain was grown in basal medium until $\mathrm{OD}_{600}$ of 0.3 and the cultivation was carried out at different inoculum sizes ranging $(0.5 \%, 1 \%$ (control), $2 \%, 3 \%$ and $4 \%$ ).

Protease activity and biomass was measured by incubating production medium seeded with different inoculum age (18 $\mathrm{h}$ (control), 1, 2 and 3 days)

Protease activity and biomass were determined for all the samples.

On the other hand, a new medium including the best contitions with nutritional and physicalfactorsfor protease production bu mutant strain were improved, and the mutant strain was grown in this modified medium. Protease and biomass yield were recorded, and compared with basal medium. 
Table 1. Diameter of the proteolytic zones of mutants on skim milk agar.

\begin{tabular}{|c|c|c|c|}
\hline $\begin{array}{l}\text { EMS Concentration } \\
\qquad(\mathrm{mg} / \mathrm{mL})\end{array}$ & $\begin{array}{l}\text { Number of } \\
\text { Colonies }\end{array}$ & $\begin{array}{l}\text { Diameter of } \\
\text { Colony } \\
(\mathrm{mm})\end{array}$ & $\begin{array}{c}\text { Diameter of } \\
\text { Proteolytic Zone } \\
(\mathrm{mm})\end{array}$ \\
\hline $\begin{array}{l}\text { Parental strain } \\
\text { (control) }\end{array}$ & 50 & 5 & 8 \\
\hline 20 & 17 & 4 & 15 \\
\hline 25 & 15 & 3 & 13 \\
\hline 30 & 10 & 4 & 11 \\
\hline 35 & 10 & 5 & 14 \\
\hline 40 & 10 & 3 & 13 \\
\hline 50 & 8 & 4 & 13 \\
\hline 55 & 7 & 3 & 12 \\
\hline 60 & 5 & 4 & 13 \\
\hline
\end{tabular}

\section{Statistical analysis}

For statistical analysis, standard deviation for each experimental results and student's t-test was calculated using Excel Spread-sheets available in Microsoft Excel. Results presented in this study are means of three independent determinations. Barscor respond to standard deviation.

\section{RESULTS and DISCUSSION}

Mutation and screening of industrially useful microorganisms are very important for the successful development of various strains which are required in the fermentation industry [19], Rao et al. [20] emphasize that mutagenesis plays an important role in increasing protease yield by conventional methods or by recombinant DNA technology.
In the present study, the parental strain was exposed to EMS between $4-400 \mathrm{mg} / \mathrm{ml}$ concentration. There was no effect of $4 \mathrm{mg} / \mathrm{ml}$ concentration on bacterial death. The $400 \mathrm{mg} / \mathrm{ml}$ and $20 \mathrm{mg} / \mathrm{ml}$ concentrations were found to be $100 \%$ and $90 \%$ lethal, respectively. At the concentration between $20-60 \mathrm{mg} / \mathrm{ml}$, the lethality rate was high and a total of 82 mutants were obtained at these concentrations. Among mutants, one mutant showed high proteolytic zone (15 $\mathrm{mm}$ ) when compare to parental type strain (8 $\mathrm{mm}$ ) (Table 1). This mutant named as Bacillus subtilis mutant KE20 (Figure 1).

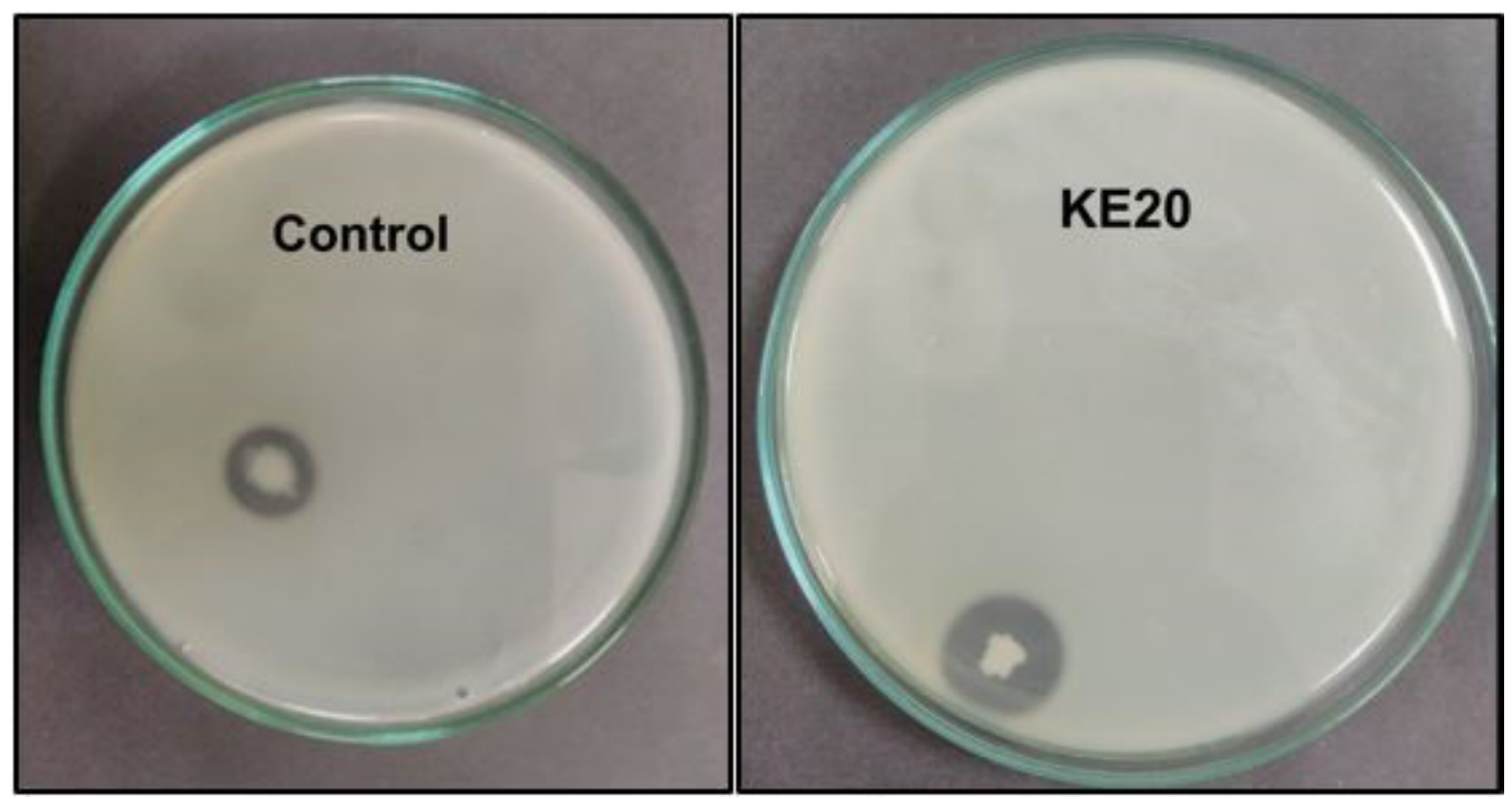

Figure 1. The appearance of parental strain (control) and mutant KE2O protease zones on skim milk agar medium. 
Table 2. Protease activities of parental strain and mutant KE20 during bacterial growth in liquid medium. Values are shown as means of triplicates.

\begin{tabular}{ccccc}
\hline \multirow{2}{*}{ Incubation time $(\mathrm{h})$} & \multicolumn{2}{c}{ Parental strain } & \multicolumn{2}{c}{ KE20 } \\
& \multicolumn{1}{c}{ Mutant } \\
\cline { 2 - 5 } & $\mathrm{IU} / \mathrm{mL}$ & $\mathrm{OD}_{600}$ & $\mathrm{IU} / \mathrm{mL}$ & $\mathrm{OD}_{600}$ \\
\hline 18 & 45 & 0,2 & 199 & 0,9 \\
\hline 24 & 48 & 0,3 & 249 & 1,0 \\
\hline 28 & 55 & 0,3 & 258 & 1,1 \\
\hline 32 & 60 & 0,2 & 270 & 1,1 \\
\hline 44 & 53 & 0,2 & 485 & 1,1 \\
\hline 48 & 51 & 0,1 & 553 & 1,1 \\
\hline 52 & 47 & 0,1 & 516 & 0,5 \\
\hline
\end{tabular}

Some researchers have used various mutagens as mutation agents in order to obtain new strains that can produce the industrially important protease enzyme at high yield reported. Among of these mutagen agents, ethyl methane sulfonate (EMS) is the most commonly used chemical mutagen for genetic manipulation of bacterial strains [21], reported that generated mutants with UV and EMS, produce a stable protease [22]. A Bacillus sp. mutant was obtained at the end of a 60 minute incubation period with 100 $\mu \mathrm{g} / \mathrm{mL}$ EMS produced 8 fold higher enzyme production [23]. Bacillus pantotheneticus and Bacillus pumilus parental strains was treatment with UV irradiation-EMS (Ethyl methanesulfonate)-MMS (Methyl methanesulfonate) combined mutagenesis [24, 25]. The results showed that mutant Bacillus pantotheneticus and mutant Bacillus pumilis M15 produced 1.44 and 1.95 fold more enzyme over the parental strains, respectively. Exposed Bacillus cereus to EMS and Ethidium bromide to increase protease production and observed an increase in enzyme production by 2-4 fold compared to the parent strain at 48 hours [26].
A mutant, Bacillus sp. APR-4, in overall a 1.24 fold increase in enzyme production over parent strain was observed after combined mutagenesis (UV-EMS at $200 \mu \mathrm{g} / \mathrm{ml}$ concentration) [14].

Bacillus sp. CAMB No. 10358 were treated with MNNG (N-methyl- N/-nitro-N-nitroso guanidine) and two mutant M-2 and M-7 were observed to be stable. The protease activity of mutants was increased by 2.74 folds when treated with the MNNG [27].

Both our results and those of other researchers have been shown that the protease production pathways of Bacillus strains and its mutans and other bacteria were very different. The frequency of spontaneous mutation varies greatly among organisms. Even within the same species, the frequency of spontaneous mutations varies from gene to gen. The variability between organisms can occur due to the relative effectiveness of their error reading and repair systems.
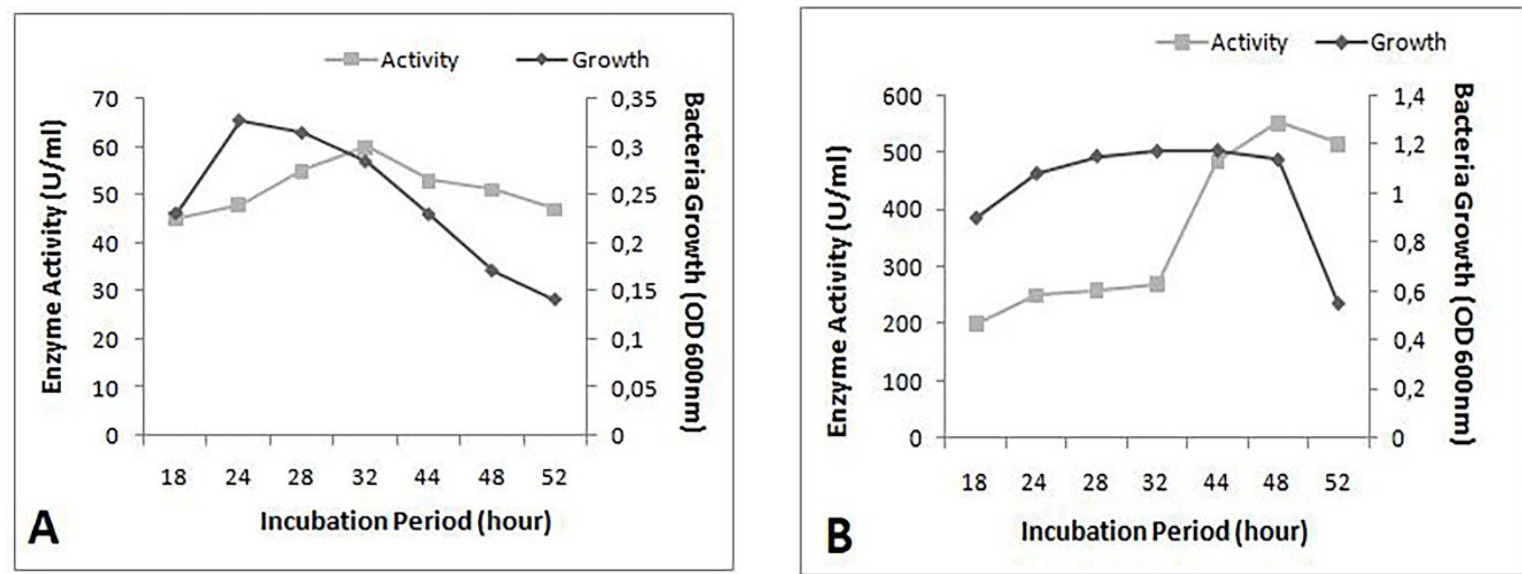

Figure 2. Enzyme activities and bacterial growth of parental strain (A) and mutant KE2O (B). 
In this study, quantitative protease production capacity of mutant KE2O has been examined in liquid medium. The maximum protease activity of parental type (60 $\mathrm{IU} / \mathrm{mL}$ ) was obtained after $32 \mathrm{~h}$, while for the mutant KE20 was $553 \mathrm{lU} / \mathrm{mL}$ after $48 \mathrm{~h}$ (Table 2) (Figure 2). The maximum enzyme production of the mutant strain was occurred at the end of the stationary phase. Protease activity and biomass increased significantly compared to parental strain. Mutant KE20 produced 9.2 fold more protease than parental strain.The mutant strain produced 4.5 times the enzyme production at $32 \mathrm{~h}$ compared to the parental strain.

Enzyme formation is largely dependent on the condition of growth of the culture and composition of nutrient medium. The present investigation was aimed at optimization of medium components which have been predicted to play a significant role in enhancing the production of protease. Hence, the nutritonal (carbon, nitrogen sources and metal ions) and physical factors (temperature, $\mathrm{pH}$, agitation, inoculum size and inoculum age (days)) were optimized to obtain high levels of protease by KE20 mutant in basal medium. When glucose in basal medium was replaced by various carbon sources, the carbon source preference ranking of Bacillus subtilis KE20 for enzyme production was determined as Corn
starch>Glucose (basal medium,control) $>$ Sucrose $>$ Maltose $>$ Fructose $>$ Potato starch $>$ Wheat bran $>$ Glycerol> Wheat starch, respectively. Although corn starch is best preferred carbon source, there is not much increase in enzyme production compared to basal (control) medium. Glycerol and wheat starch caused reduced protease synthesis. Bacterial growth was not parallel with enzyme production (Figure 3).But, bacterial growth was not parallel with enzyme production (Figure 3).

Nitrogen sources also affected enzyme production. Therefore, effects of various organic and inorganic nitrogen sources on production of protease were investigated. Results showed that the best nitrogen source for protease production by mutant KE20 was skim milk, and enzyme yield was $13 \%$ compare to basal medium. On the other hand, inorganic sources did not promoteprotease production. Enzyme activity was not observed in the presence of $\left(\mathrm{NH}_{4}\right)_{2} \mathrm{SO}_{4}$. Bacterial growth was not parallel with enzyme production (Figure 4).

Metal ions in media are an important factor that affects enzyme production due to act as inducers. The effects of some metal ions on protease activities were investigated. But, in present studies showed that metal ion addition to the fermentation medium does not effect

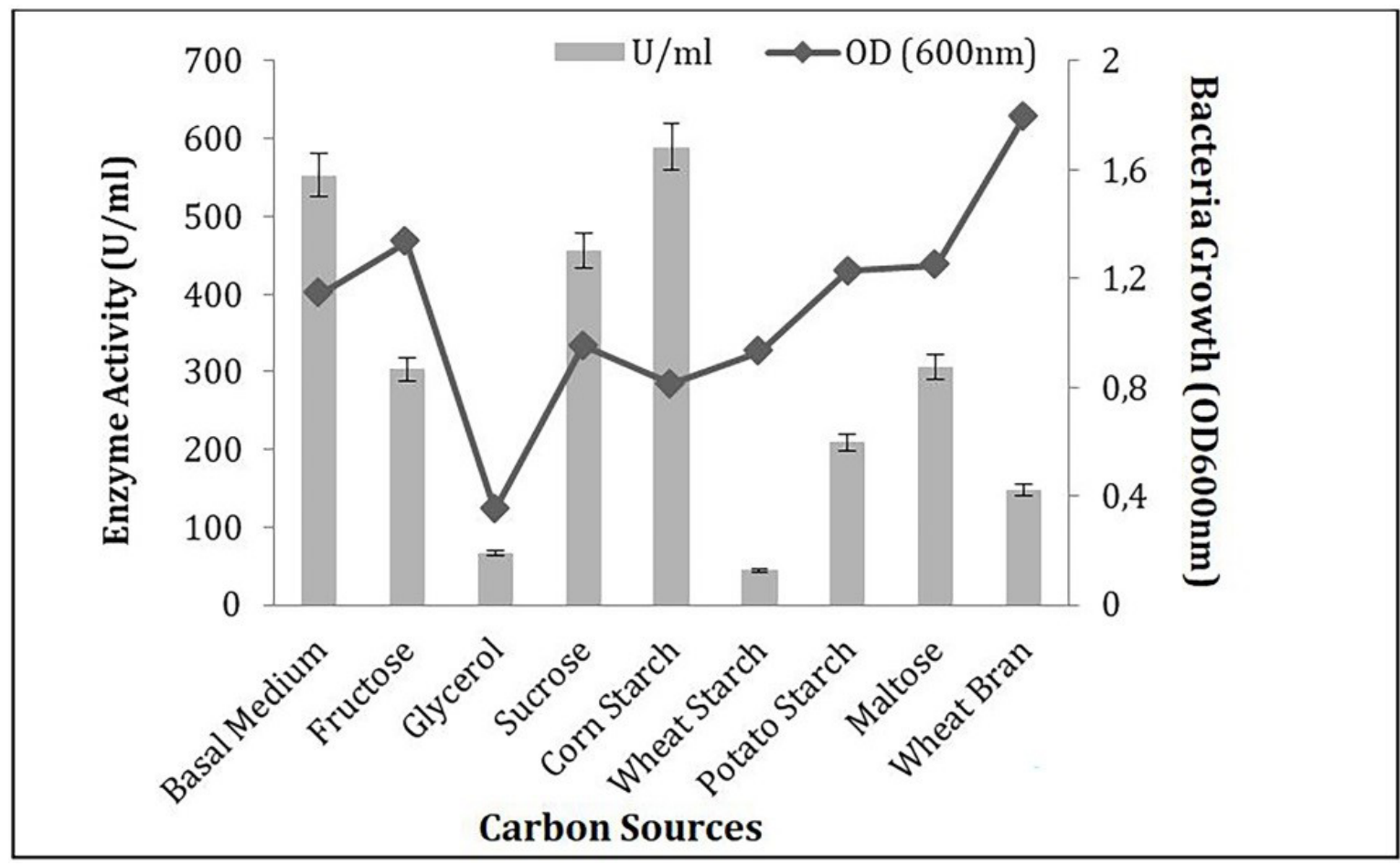

Figure 3. Effect of carbon sources on protease production by KE2O. Results are means of three independent determinations. Bars correspond to standard deviation. 


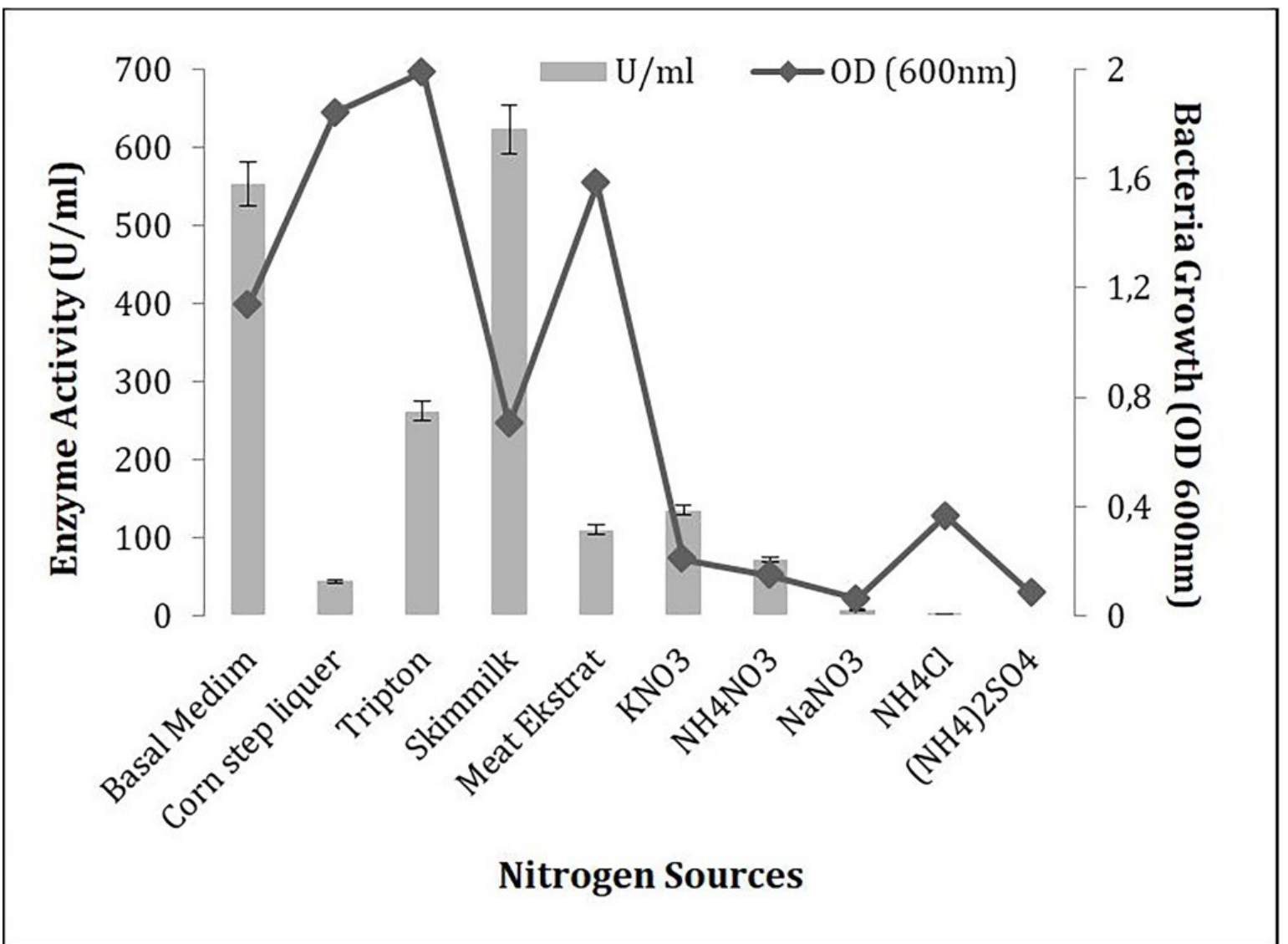

Figure 4. Effect of organic and inorganic nitrogen sources on protease production by KE2O. Results are means of three independent determinations. Bars correspond to standard deviation.

in enzyme activity (Figure 5). When $\mathrm{MgSO}_{4}$ and $\mathrm{CaCl}_{2}$, both of which are found in the basal environment, are used alone, the enzyme production was decreased. It was determined that $\mathrm{MgSO}_{4}$ and $\mathrm{CaCl}_{2}$ operate together and do not have any more effect when considered separately has been reported the similar result with $\mathrm{MgSO}_{4}[28]$.

Reserachers have been reported different results for nutritonal (carbon, nitrogen sources and metal ions) factors. Mehrotra et al. [29] mutant Bacillus sp. strain of glucose, Mabrouk et al. [30] also reported the highest level of protease production in the presence of lactose and glucose. Mukhtar and Haq [31] have been exposed Bacillus subtilis strain to EMS mutation in order to increase alkaline protease production. They isolated 14 strongest mutants and observed enzyme production and, achieved approximately high yield using soy flour, polypeptone, yeast extract, glucose, $\mathrm{NH}_{4} \mathrm{SO}_{4}$ and $\mathrm{Na}_{2} \mathrm{CO}_{3}$. Leng and $\mathrm{Xu}$ [32] found the best nitrogen source for protease production as peptone, followed by soy flourand yeast extract. Fawzi [33] found that organic nitrogen sources are superior to inorganic nitrogen in enzyme production. Raju and Divakar [26] reported that Bacillus cereus GD55 mutant with treathment UV-EMS- EtBr the best protease production from in the presence of fructose as carbon source, peptone as organic nitrogen source and $\mathrm{NH} 4 \mathrm{NO} 3$ as inorganic nitrogen source. The best carbon source for the Aspergillus oryzae mutant obtained by EMS treatment has been explained to be sucrose [34], and for the Bacillus cereus mutant was glucose and fructose [35].

Environmental conditions could affect the production of extracellular enzymes. Some physical factots (temperature, $\mathrm{pH}$, agitation, inoculum size and inoculum age) were studied for its influence in protease production of mutant KE20. As seen in Figure 6, incubation temperature $37^{\circ} \mathrm{C}$ was found to be the best for protease production. This is 


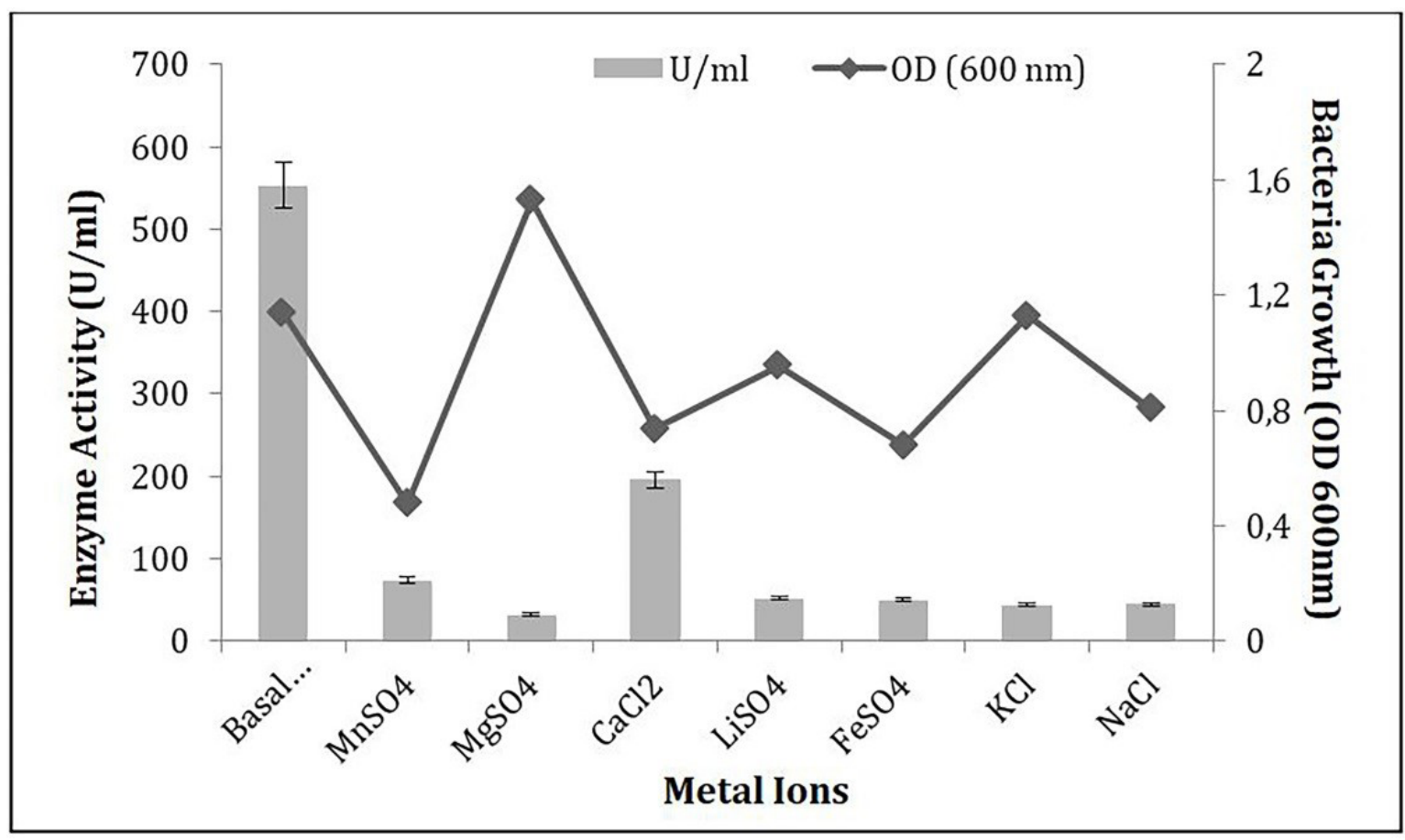

Figure 5. Effect of metal ions on protease production on protease production by KE20. Results are means of three independent determinations. Bars correspond to standard deviation.

expected, since the tested mutant is mesophilic. As the temperature increased, a dramatic decrease in growth and enzyme activity was observed.

Various $\mathrm{pH}$, ranging from $\mathrm{pH} 4.0$ to $\mathrm{pH} 8.0$ were tested to determine the optimum $\mathrm{pH}$ for protease production. In this study, the maximum production was observed at pH 7.0 (Figure 7) The enzyme is a neutral enzyme. In acidic $\mathrm{pHs}$, there was a considerable decrease in gwroth and enzyme activity. Most commercial neutral and alkaline proteases are produced by members of the genus Bacillus. Neutral proteases of bacteria are active at a narrow $\mathrm{pH}$ range $(\mathrm{pH}$ 5.0-8.0) [36].

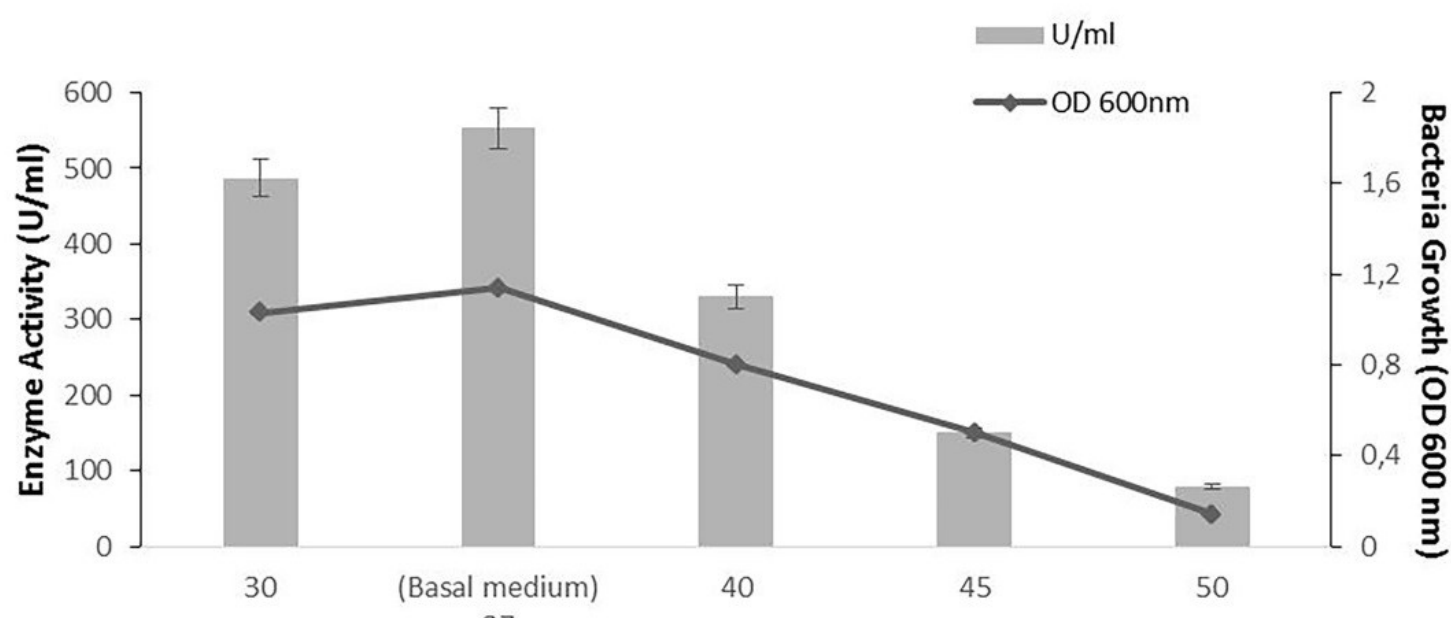

37

Temperature ${ }^{\circ} \mathrm{C}$

Figure 6. Effect of temperature on protease production on protease production by KE20. Results are means of three independent determinations. Bars correspond to standard deviation. 


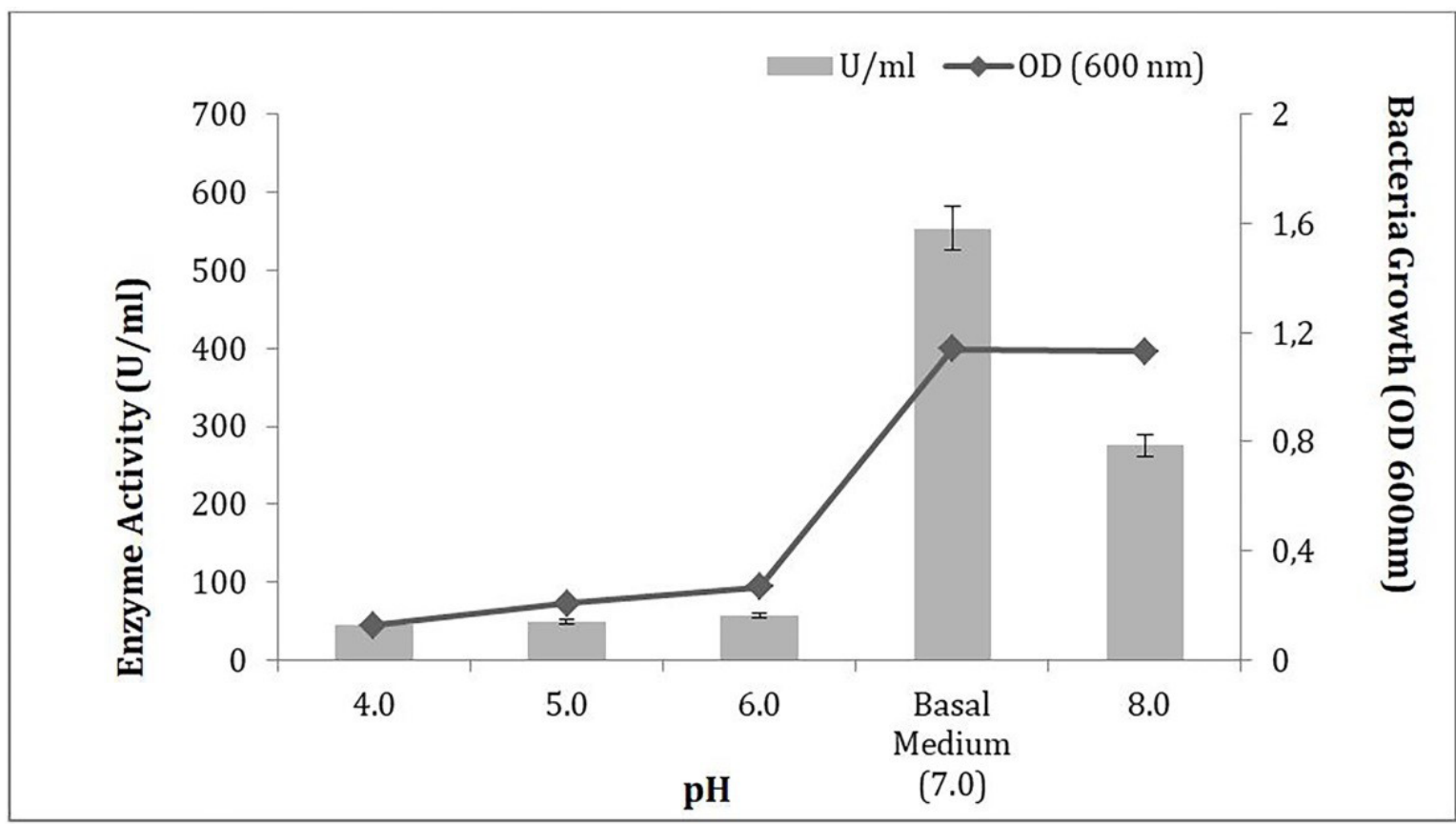

Figure 7. Effect of $\mathrm{pH}$ on protease production on protease production by KE20. Results are means of three independent determinations. Bars correspond to standard deviation.

Agitation leads to better dispersion of substrate, nutrients and oxygen in medium. The optimum agitation rate for protease production was $150 \mathrm{rpm}$ (Figure 8). There was a gradual rise in enzyme production and growth with increasing agitation rates. But, enzyme yield at $200 \mathrm{rpm}$ was very low. It has not been observed that higher agitation rates was much better for enzyme production.

Inoculum size plays an important role in fermentation process; in a suitable inoculum size, sufficient amount of nutrient and oxygen will be accessible for growth. In the present investigation, the mutant KE20 grown in basal culture medium with different inoculum size. The results show that the production of protease increased of size of inoculum reaching its maximum at $3 \%$ (Figure 8 ). Protease yield and biomass formation had paralel. The best amount of inoculation was determined as $3 \%$.

The inoculum age is of importance when using mesophilic organisms due to the relatively low growth rate. In this study, the maximum enzyme production was observed with $18 \mathrm{~h}$ culture (Figure 8). Use of old cultures as inoculum resulted in decreased protease activity and growth. Because much increase in inoculum age caused overcrowding of spore that decreased the enzyme activity.

In studies with Bacillus mutants, researchers have been investigated the effect of physical factors.
Mukhtar and Haq [37] exposed the Bacillus subtilis strain to the EMS mutation in order to increase alkali protease production and determined the best enzyme production in $\mathrm{pH} 8.5$ Nadeem et al. [13] in their study of alkaline protease from Bacillus pumilus mutant strain exposed to EMS, the maximum protease activity was obtained at $\mathrm{pH} 10.0$ and $60^{\circ} \mathrm{C}$. The maximum protease production by mutant Bacillus cereus GD55 was observed with inoculum size level $2 \%, \mathrm{pH} 8.0$, temperature $35^{\circ} \mathrm{C}(28.68 \pm 0.19 \mathrm{U} / \mathrm{ml})$, and incubation time 48 hours in the production medium [26].

Latif et al. [38] reported that maximum protease procution of mutant Bacillus subtilis 60 was determined at $\mathrm{pH} 10$, temperature $35^{\circ} \mathrm{C}$, inoculum size $4 \mathrm{~mL}$ and fermentation time $120 \mathrm{~h}$ The optimum temperature and $\mathrm{pH}$ were found to be $30^{\circ} \mathrm{C}$ and 10 for mutant Bacillus sp. CAMB No. 10358 8 [27]. Pseudomonas sp. has been reported that $1.5 \%$ inoculum showed maximum enzyme production [39].

Both our results and those of other researchers have been shown that the protease production pathways of Bacillus strains were very different.

In this study, nutritional and physical parameters were optimized for enhanced production of protease by mutant Bacillus subtilis KE20. By optimizing the incubation conditions of protease production from this mutant was enhanced $79 \%$ enzyme yield as compared to basal medium 

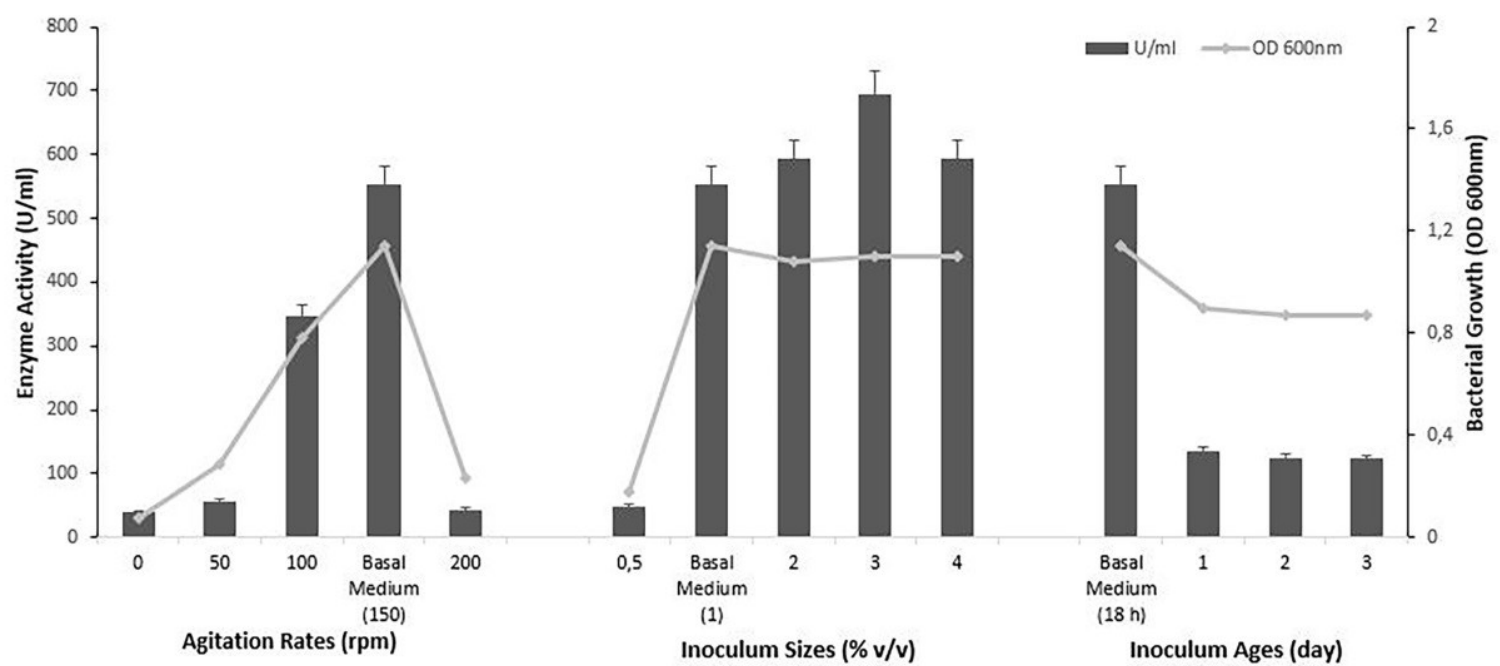

Figure 8. Effects of agitation rate, inoculum size and inoculum age on on protease production by KE20. Results are means of three independent determinations. Bars correspond to standard deviation.

(control). In addition, the mutant KE20 yielded 16.5 fold increase compared to the parental strain.

The protease enzyme studied in this research is an enzyme that is used in different branches of industry and has an increasing rate of use every day. Bacillus subtilis KE2O protease enzyme, which is a very efficient and new mutant obtained as a result of the study, may have industrial usability.

\section{References}

1. D.S. Ningthoujam, P. Kshetri, P. Sanasam, S. Nimaichand, Screening identification of best producers and optimization of extracellular proteases from moderately halophilic alkali thermotolerant indigenous actinomycetes, World Appl. Sci. J., 7 (2009) 907-916.

2. K.M. Sharma, R. Kumar, S. Panwar, A. Kumar, Microbial alkaline proteases: optimization of production parameters and their properties, J. Genet. Eng. Biotechnol., 15 (2017) 115-126.

3. A. Belmessikh, H. Boukhalfa, A. Mechakra-Maza, Statistical optimization of culture medium for neutral protease production by Aspergillus oryzae comparative study between solid and submerged fermentations on tomato pomace, J. Taiwan Inst. Chem. Eng., 44 (2013) 377-385.

4. Z. Chi, C. Ma, P. Wang, Optimization of medium and cultivation conditions for alkaline protease production by the marine yeast Aureobasidium pullulans, Bioresour. Tech., 98 (2007) 534-538.

5. E. Bach, V. Sant'Anna, D.J. Daroit, Production one-step purification and characterization of a keratinolytic protease from Serratia marcescens P3, Process Biochem., 47 (2012) $2455-2462$.
6. F.J. Contesini, R.R. Melo, H.H. Sato, An overview of Bacillus proteases from production to application, Crit. Rev. Biotechnol., 38 (208) 321-334.

7. R. Gupta, Q.K. Beg, P. Lorenz, Bacterial alkaline proteases molecular approaches and industrial applications, App. Microbiol. Biotech., 59 (2002) 15-32.

8. S. Singh, V. Sharma, M.L. Soni, S. Das, Biotechnological applications of industrially important amylase. Int. J. Pharma. Bio. Sci., 2 (2011) 487-496.

9. D.A. Azin, R.F. Noroozi, Effect of chemicals on the improved gluconate productivity by an Aspergillus niger strain, Appl. Biochem. Biotech. Appl. Biochem., 61 (2001) 393-397.

10. M. Munazzah, A.J. Khalil-ur-Rahman, A. Muhammad, R. Ibraheem, J. Sadia, J. Nazish, Bacillus subtilis improvement through UV and chemical mutagenesis for indigenously hyperproduced urate oxidase, Pak. J. Life. Soc. Sci., 10 (2012) 123-129.

11. O. Ribeiro, F. Magalhaes, T.Q. Aguiar, M. Wiebe, M. Penttila, L. Domingues, Random and direct mutagenesis to enhance protein secretion in Ashbya gossypii, Bioengineered, 4 (2013) 322-331.

12. E.A.M. Soliman, W.K. Hegazy, E.M. Maysa, Induction of overproducing alkaline protease Bacillus mutants through UV irradiation. Arab. J. Biotech., 8 (2004) 49-60.

13. M. Nadeem, J.I. Qazi, Enhanced production of alkaline protease by a mutant of Bacillus licheniformis $\mathrm{N}-2$ for dehairing, Braz. Arch. Biol. Technol., 53 (2010) 1015-1025.

14. N. Thakur, T.C. Bhalla, D. Kumar, Systemic mutagenesis of Bacillus sp. APR-4 for enhanced production of thermostable and alkaline protease, Biol. Forum., 9 (2017) 54-60.

15. E. Demirkan, D. Kut, T. Sevgi, M. Dogan, E. Baygin, Investigation of effects of protease enzyme produced by Bacillus subtilis 168 E6-5 and commercial enzyme on physical properties of woolen fabric, J. Text. I., 111 (2020) 26-35.

16. H. Zong, Y. Zhan, X. Li, L. Peng, F. Feng, D. Li, A new mutation breeding method for Streptomyces albulus by an atmospheric and room temperature plasma, Afr. J. Microbiol. Res., 6 (2012) 3154-3158. 
17. S.A. Quadar, E. Shireen, S. Iqbal, A. Anwar, Optimization of protease production from newly isolated strain of Bacillus sp. PCSIR EA-3. Indian J. Biotechnol., 8 (2009) 286-290.

18. L. Keay, B.S. Wildi, Proteinases of the genus Bacillus. I. Neutral proteases, Biotechnol. Bioeng., 12 (1970) 179-212.

19. J.R. Dutta, R. Banerjee, Isolation and characterization of a newly isolated Pseudomonas mutant for protease production, Braz. Arch. Biol. Technol., 49 (2006) 37-47.

20. B.M. Rao, M.A. Tanksale, S.M. Ghathe, V.V Deshpande, Molecular and biotechnological aspects of microbial proteases, Microbiol. Mol. Biol. Rev., 62 (1998) 597-635.

21. I. Haq, S. Ali, M.M. Javed, U. Hameed, A. Saleem, F. Adnan, M.A. Qadeer, Production of alpha amylase from a randomly induced mutant strain of Bacillus amyloliquefaciens and its application as a desizer in textile industry, Pak. J. Bot., 42 (2010) 473-484.

22. N. Rakariyatham, B. Butr-Indr, H. Niamsup, L. Shank, Improvement of myrosinase activity of Aspergillus sp.NR4617 by chemical mutagenesis, Electron. J. Biotechn., 9 (2006) 379- 385.

23. I.M. Meraz, T. Choudhary, M.M. Hoq, Optimization of mutation conditions of Bacillus sp. to increase the yield of alkaline protease, FEMS Microbial. Lett., 66 (2005) 239- 244.

24. Shikha, A. Sharan, N.S. Darmwal, Improved production of alkaline protease from a mutant of alkalophilic Bacillus pantotheneticus using molasses as a substrate, Bioresour. Technol., 98 (2007) 881-885.

25. M. Nadeem, Q. Syed, A. Liaquat, S. Baig, A. Kashmiri, Study on biosynthesis of alkaline protease by mutagenized culture of Bacillus pumilus, Pak. J. Food Sci., 20 (2011) 24-30.

26. E.V.N. Raju, and G. Divakar, Bacillus cereus GD 55 Strain Improvement by Physical and Chemical Mutagenesis for Enhanced Production of Fibrinolytic Protease, Int. J. Pharm. Sci. Res., 4 (2013) 81-93.

27. M. Hussain, A.K. Chaudhary, H. Bashir, Enhance production of alkaline protease by chemical mutagenesis of Bacillus species, Biocell, 43 (2019) 312-322.

28. S. Mrudula, B.A. Apsana, K. Ashwitha, P.K. Pindi, Enhanced Production of Alkaline Protease By Bacillus subtilis in Submerged Fermentation, Int. J. Pharm. Bio. Sci., 3 (2012) 619-631.
29. S. Mehrotra, P.K. Gaur, N.S. Darmwai, The production of alkaline protease by a Bacillus species isolate, Bioresour. Technol., 67 (1999) 201- 203.

30. S.S. Mabrouk, A.M. Hashem, N.M.A El-Shhayeb, A.S. Ismail, A.F. Abdel-Fattah, Optimization of alkaline protease productivity by Bacillus licheniformis ATCC21415, Bioresour. Technol., 69 (1999) 155-159.

31. H. Mukhtar, I. Haq, Optimization of volume of fermentation medium for the production of alkaline protease by an ems mutant strain of Bacillus subtilis, Pak. J. Bot., 39 (2007) 27052715 .

32. X.W. Leng, Y. Xu, Improvement of acid protease production by a mixed culture of Aspergillus nigerand, Aspergillus oryzaeusing solid state fermentation technique, Afr. J. Biotechnol., 10 (2011) 6824- 6829.

33. E. Fawzi, Comparative study of two purified inulinases from Thermophilethielavia terrestris NRRL 8126 and mesophile Aspergillus foetidus NRRL 337 grown on Cichorium intybus, Braz. J. Microbiol., 42 (2011) 633-649.

34. Y. Muhammad, M. Irfan, Z.U. Khokhar, Q.A. Syed, S. Baig, A. Iqbal, Enhanced production of protease by mutagenized strain of Aspergillus oryzae in solid substrate fermentation of rice bran, Sci. Int. 22 (2010) 119-123.

35. T.V. Sivakumar, T. Ramasubramanian, P. Shankar, Screening of keratinolytic bacteria Bacillus cereus from the feather dumping soil of sivakasi, Insight Bacteriol., 1 (2012) 1-6.

36. M. Kuddus, Enzymes in Food Biotechnology, production, applications, and future prospects, 1st Edition, Academic Press, San Diego-California, U.S.A., (2018).

37. H. Mukhtar, I. Haq, Production of alkaline protease by Bacillus subtilis and its application as a depilating agent in leather processing, Pak. J. Bot., 40 (2008) 1673-1679.

38. A. Latif, M. Iqbal, M. Asgher, Ethyl Methane Sulfonate Chemical Mutagenesis of Bacillus subtilis for Enhanced Production of Protease, Org. Med. Chem. Int. J., 5 (2018) 555664.

39. J.R. Dutta, P.K. Dutta, R. Banerjee, Optimization of culture parameters for extracellular protease production from a newly isolated Pseudomonas sp. using response surface and artificial neural network models, Process Biochem, 39 (2004) 2193-2198 